\title{
Ujaran Kebencian di Ruang Publik: Analisis Pragmatik pada Data Pusat Studi Agama dan Perdamaian (PSAP) Solo Raya
}

\author{
Dwi Kurniasih ${ }^{\mathrm{a}, 1, *}$ \\ ${ }^{a}$ Institut Agama Islam Negeri (IAIN) Surakarta, Jawa Tengah 57168, Indonesia \\ ${ }^{1}$ dwikurniasih445@gmail.com*
}

ARTICLE INFO

ABSTRACT

Article history:

Received : 2019-01-31

Revised : 2019-05-15

Accepted : 2019-05-27

Keywords:

Hate Speech

Pragmatics

PSAP Solo Raya

Kata Kunci:

Ujaran Kebencian

Pragmatik

PSAP Solo Raya
This study aims to explain the forms of speech hate in the public space using pragmatic theory, especially acts of perlokusi speech. In addition, this research also explains the actualization of the Solo Raya Center for Religion and Peace Studies in minimizing the utterances of hatred in the public sphere. The method used in this study is descriptive qualitative. Data is obtained from hate speech monitored by PSAP for the period January-December 2017 until January-July 2018. Data is a word or sentence in the form of banners and the like with utterances of hate spread in public spaces. The results of the study show that all forms of speech if associated with pragmatic science, are all included in the category of perlocution speech acts, because they all lead to the power of one's influence or cause bad stereotypes. Based on the class of hate speech forms, the data presented is classified into several types of hate speech, namely (1) insult; (2) provocation; (3) oppression; (4) speech of crime. In addition, a forum for communication and discussion is needed to erode speeches of hatred. For example, the formation of the Solo Raya PSAP institution as a form of minimizing the utterance of hate in the public space.

\section{ABSTRAK}

Penelitian ini bertujuan untuk mengeksplanasikan bentuk-bentuk ujaran kebencian di ruang publik menggunakan teori pragmatik khususnya tindak tutur perlokusi. Selain itu, penelitian ini juga menjelaskan bentuk aktualisasi Pusat Studi Agama dan Perdamaian (PSAP) Solo Raya dalam meminimalisasi ujaran kebencian di ruang publik. Metode yang digunakan dalam penelitian ini adalah deskriptif kualitatif. Data diperoleh dari ujaran kebencian yang dipantau oleh PSAP periode JanuariDesember 2017 sampai Januari-Juli 2018.Data merupakan kata atau kalimat berupa spanduk dan sejenisnya dengan unsur ujaran kebencian yang disebarkan di ruang publik. Hasil dari penelitian menunjukkan semua bentuk ujaran jika dikaitkan dengan keilmuan pragmatik, maka semuanya termasuk dalam kategori tindak tutur perlokusi, sebab semuanya mengarah pada daya pengaruh seseorang atau menimbulkan stereotip buruk. Berdasarkan kelas bentuk-bentuk ujaran kebencian, maka data yang dipaparkan tergolong ke dalam beberapa jenis ujaran kebencian yakni, (1) penghinaan; (2) provokasi; (3) penindasan; (4) ujaran kejahatan. Selain itu, diperlukan wadah sebagai sarana komunikasi dan diskusi untuk mengikis ujaran-ujaran kebencian. Misalnya terbentuknya lembaga PSAP Solo Raya sebagai salah satu wujud minimalisasi ujaran kebencian di ruang publik.

\section{Pendahuluan}

Ujaran kebencian merupakan ujaran yang mempunyai unsur-unsur seperti segala tindakan dan usaha baik langsung maupun tidak langsung yang didasarkan pada kebencian atas dasar suku, agama, aliran keagamaan, keyakinan atau kepercayaan, ras, atau antar golongan yang dilakukan melalui berbagai sarana.(7) Ujaran kebencian adalah 
bentuk dari sikap intoleran, unlike, ketidaksukaan pada kelompok masyarakat lain.

Konsep ujaran kebencian ini merujuk pada ekspresi ketidaksukaan berupa menghasut, memprovokasi, menyebarkan, dan membenarkan kebencian yang berkaitan dengan suku, ras dan agama. Ujaran kebencian dinilai sebagai bentuk ungkapan untuk menyerang dan mendorong terjadinya kekerasan baik verbal maupun noverbal. Dengan demikian, dalam mengungkapkan kebebasan berekspresi harus mempertimbangkan kembali isi pesan yang dibuat melalui pemikiran dan rasa yang mendalam.(9) Kebebasan berekspresi yang tidak mengikuti norma bisa jadi mengarah pada suatu ujaran kebencian (hate speech) (5).

Kebebasan berpendapat maupun mengkritik seseorang yang dianggap tidak akan melanggar norma dan aturan apapun, karena dianggap tidak adanya kontak fisik langsung dengan orang lain (14). Isu yang paling sensitif terkait ujaran kebencian adalah agama. Siar kebencian agama tidak dapat dilepaskan akar kebencian berbasis agama atau keyakinan yang muncul dan tumbuh berkembang di dalam masyarakat, terlepas ada atau tidaknya kebijakan formal yang bersifat intoleran atau diskriminatif. Akibat ekstremnya ajaran Islam yang salah, maka yang terjadi adalah sekarang peradaban yang sebelumnya kokoh itu hancur seketika karena kebencian (2).

Salah satu bentuk usaha dalam menangkal ujaran kebencian adalah menciptakan wadah yang bertujuan meminimalisasi ujaran kebencian. Seperti lembaga Pusat Studi Agama dan Perdamaian (PSAP) yang berpusat di Solo Raya. Lembaga ini berdiri salah satunya dilatarbelakangi oleh beragamnya pemeluk keyakinan di kota Solo. Solo merupakan kota yang memiliki keragaman, baik dari sisi sosial, politik dan agamanya. Kenyataan ini merupakan potensi yang besar untuk kemajuan Solo jika dikelola dengan baik, namun akan menjadi bencana jika keragaman tersebut dibiarkan. Berangkat dari tersebut, pada tahun 2013 didirikan Pusat
Studi Agama dan Perdamaian (PSAP). Dalam lembaga ini tergabung individu-individu yang berlatarbelakang aktivis sosial, peneliti, akademisi, tokoh agama dan tokoh budaya yang ada di Solo. Degup PSAP Solo Raya selama beberapa tahun terakhir adalah memantau bentuk-bentuk ujaran kebencian yang tersebar di ruang publik. PSAP bersama tim membentuk jaringan untuk menggali informasi terkait ujaran kebencian.

Penelitian ini menggunakan pisau analisis pragmatik untuk menganalisis data-data ujaran kebencian, sebab data berupa tindak tutur yang menarik. Secara sederhana, pragmatik merupakan kajian linguistik makro yang bertujuan untuk menyampaikan maksud kepada seseorang,(11) menyampaikan bahwa pragmatik adalah studi tentang makna yang disampaikan oleh penutur dan ditafsirkan oleh pendengar. Lebih lanjut, menurut Wijana pragmatik adalah ilmu yang mempelajari tentang makna, akan tetapi makna yang dikaji oleh pragmatik adalah makna yang memiliki keterkaitan konteks.(17) Hal tersebut sejalan dengan pendapat Lavinson, pragmatik merupakan salah satu kajian ilmu bahasa yang mengkaji hubungan antara bahasa dan konteksnya, sehingga menjadi dasar penentuan pemahaman.(12)

Studi pragmatik memiliki beberapa cabang, salah satunya adalah tindak tutur. Tindak tutur merupakan fenomena pragmatik yang memiliki daya tarik apabila diteliti. Searle mengemukakan bahwa secara pragmatik ada tiga jenis yang dapat diwujudkan oleh seorang penutur, yakni tindak tutur lokusi, tindak tutur ilokusi dan tindak tutur perlokusi. Dengan demikian, data-data ujaran kebencian akan dikaji berdasarkan keilmuan pragmatik khususnya bentuk tindak tutur. Akan tetapi, data dalam penelitian ini difokuskan pada tindak tutur perlokusi yang berimplikasi pada perbuatan seseorang dengan ujaran yang memengaruhi pola pikir. Tindak perlokusi merujuk pada efek yang dihasilkan penutur dengan mengatakan atau melakukan suatu tindakan. (6) Tindak perlokusi merupakan tindak tuturan yang pengutaraannya dimaksudkan untuk mempengaruhi lawan tutur. Tuturan 
yang diutarakan seseorang sering kali mempunyai daya pengaruh atau efek bagi yang mendengarnya. Tindak tutur ini dapat disebut dengan the act of effecting someone (15).

Dari penjelasan di atas penelitian ini akan membahas tentang bentuk-bentuk ujaran kebencian di ruang publik berdasarkan analisis pragmatik yang dikhususkan pada tindak tutur perlokusi. Urgensi dari penelitian ini adalah pentingnya pemahaman tentang bentuk-bentuk kata atau kalimat yang pada dasarnya mengandung ujaran kebencian. Terlebih ujaran-ujaran yang tersebar di ruang publik dan bersifat perlokusi atau dapat menimbulkan pengaruh bagi pembaca.

Penelitian ini juga akan melihat bagaimana Pusat Studi Agama Perdamaian (PSAP) Solo Raya meminimalisasi ujaran kebencian di ruang publik. Dengan pengenalan lembaga, komunitas, atau organisasi seperti PSAP diharapkan dari penelitian ini akan menimbulkan keinginan bagi pembaca untuk membentuk komunitas sosial kemanusiaan yang memiliki kontribusi untuk meminimalisasi ujaran kebencian. Dengan demikian, akan terbentuk lapisan kemanusiaan yang damai tanpa ada syiar kebencian, sebab pada dasarnya kebencian akan memecah belah sedang kedaiaman akan mempersatukan perbedaan.

\section{Tinjauan Pustaka}

Di Indonesia, istilah ujaran kebencian belum terlalu dipahami. Banyak pihak yang kerap kesulitan membedakan apakah suatu ucapan atau ekspresi termasuk ke dalam kategori ujaran kebencian. Secara umum, ujaran kebencian dapat diartikan sebagai ucapan yang bertujuan untuk menyinggung, menghina, mengintimidasi, atau mengancam seseorang atau suatu kelompok tertentu berdasarkan agama, etnis, ras, gender, kedisabilitasan, atau orientasi seksual. Ujaran kebencian yang saat ini marak terjadi mempunyai potensi untuk menciderai penghormatan terhadap kemajemukan dan keberagaman yang menjadi nilai pokok masyarakat Indonesia.(18) Seperti yang diidentifikasikan oleh Komnas HAM, ujaran kebencian membuka peluang bagi berkembangnya praktik diskriminasi dan kekerasan terhadap kelompok agama, ras, dan etnis minoritas, bahkan jika dibiarkan tanpa kendali bisa mendorong tindak kekerasan terhadap kelompok minoritas.

Penelitian terkait ujaran kebencian pernah dilakukan oleh Yuliana dkk dalam prosiding Seminar Nasional Teknologi Informasi dan Bisnis (SENATIB) 2017. Hasil penelitian menunjukkan bahwa 107 status foto yang diunggah 67 atau $62,6 \%$ status foto memicu timbulnya komentar dalam bentuk ujaran kebencian. Status foto yang tidak memicu timbulnya komentar dalam bentuk ujaran kebencian sebanyak 40 atau 37,4\%.(19) Penelitian serupa juga pernah dilakukan oleh Mawarti (13) yang dimuat dalam jurnal TOLERANSI: Media Komunikasi Umat Beragama. Hasil penelitian menunjukkan maka hate speech yang ada di dunia maya, akan berpengaruh pada diri seseorang. Lebihlebih jika mereka adalah pelaku. Hal ini berdasarkan juga pada hasil beberapa riset di atas, bahwa hate speech memberikan dampak beragam pada diri seseorang.

Penelitian yang akan dilakukan memiliki perbedaan yakni, penelitian ini fokus pada ujaran kebencian di ruang publik berdasarkan data Pusat Studi Agama dan Perdamaian (PSAP) Solo Raya. PSAP Solo Raya terbentuk sekitar tahun 2014. Beberapa faktor yang melatarbelakangi dibentuknya PSAP di wilayah Solo dan sekitarnya adalah banyak kasus kekerasan, konflik di antara umat, maka diperlukan adanya lembaga yang dapat berperan dalam hal kebencian dan perpecahan.

\section{Metode Penelitian}

Penelitian ini menggunakan metode deskriptif kualitatif. Metode deskriptif kualitatif merupakan metode yang memberikan gambaran atau uraian atas suatu keadaan sejelas mungkin tanpa ada perlakuan terhadap objek yang diteliti.(8) Secara sederhana penelitian menggunakan metode deskriptif kualitatif merupakan metode yang berusaha menggambarkan objek secara kenyataan dan apa adanya. Data dari penelitian ini adalah bentuk-bentuk ujaran kebencian yang dikumpulkan oleh Pusat Studi Agama Perdamaian (PSAP) Solo Raya periode Januari 2017 sampai dengan Juli 
2018. Data merupakan kata atau kalimat berupa spanduk dan sejenisnya dengan unsur ujaran kebencian yang disebarkan di ruang publik menggunakan kajian pragmatik.

Teknik analisis data dengan mengklasifikasikan data yang meliputi lokusi, ilokusi, dan perlokusi. Kemudian hanya mengambil data yang berupa tindak tutur perlokusi sesuai dengan tujuan penelitian. Setelah data diklasifikasikan, langkah selanjutnya adalah menganalisisnya. Analisis menggunakan keilmuan pragmatik tidak dapat terlepas dari konteks. Pemahaman konteks sangat diperlukan dalam menganalisis pragmatik. Konteks merupakan segala aspek yang berkaitan dengan lingkungan fisik dan sosial sebuah tuturan. Leech mengartikan konteks sebagai pengetahuan latar belakang tuturan yang sama-sama dimiliki baik oleh penutur maupun petutur yang membantu petutur untuk menafsirkan makna tuturan. (10) Oleh sebab itu, dalam penelitian ini menggunakan konteks atau situasi yang memunculkan ujaran kebencian berupa kalimat perlokusi.

\section{Hasil dan Diskusi}

\section{a. Bentuk-bentuk Ujaran Kebencian di Ruang Publik dalam Lingkup Pragmatik}

Ujaran kebencian dapat pula diartikan sebagai tindak tutur yang disampaikan oleh penutur kepada mitra tutur. Bentuk tindak tutur memiliki pengaruh tertentu terhadap mitra tutur atau antara pengirim dengan penerima. Salah satunya adalah tindak tutur perlokusi. Tindak perlokusi disebut sebagai "The Act of Affecting Someone". Tuturan yang diucapkan oleh seseorang penutur sering kali memiliki efek atau daya pengaruh (perlocutionary force) bagi yang mendengarkannya. Efek atau daya pengaruh ini dapat terjadi karena disengaja ataupun tidak disengaja oleh penuturnya. Efek yang dihasilkan dengan mengujarkan sesuatu itulah disebut tindak perlokusi.(4) Berikut data ujaran kebencian satu tahun terakhir yang diperoleh PSAP Solo Raya.

Data pertama, Kasus Pembangunan Gedung MTA

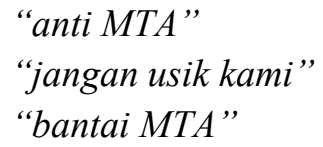

Tindak tutur pada data di atas termasuk bentuk ujaran yang memberikan efek tindakan. Salah satunya adalah "bantai MTA." Ujaran tersebut tidak hanya membuat seseorang melakukan suatu tindakan yang berupa pembantaian atau kekerasan terhadap MTA, akan tetapi juga membentuk pola pikir untuk membenci dan anti-MTA. Hal ini sesuai dengan tindak tutur perlokusi yang merupakan sebuah tuturan yang diutarakan oleh seseorang seringkali mempunyai daya pengaruh (perlocutionary force) atau efek bagi yang mendengarkannya.(10) menyatakan bahwa pragmatik sebagai studi tentang makna dalam hubungannya dengan situasi-situasi ujar (speech situation). Berikut konteks yang terjadi dalam situasi ujaran penolakan MTA.

Penolakan terhadap keberadaan Majelis Tafsir Alquran kembali terjadi di Solo raya, terutama di Karanganyar. Konflik ini ini berawal dari intoleransi sampai dengan konflik di masyarakat Jatiwarno, Jatipuro karanganyar. Puncaknya adalah pada 2 Februari 2017 warga memblokade jalan akses masuk menuju gedung baru Majelis Tafsir Alquran (MTA) di Dukuh Wates, Dusun Jangglengan, Desa Jatiwarno. Warga masyarakat sempat menghimbau jemaah MTA yang datang dari luar desa tersebut untuk tidak jadi mengukuti pembukaan sekaligus pengajian perdana di gedung baru tersebut. Salah satunya "sampai kapanpun warga Bentangan menolak segala aktivitas MTA di dukuh Bentagan. "Kami Siap melawan". Kondisi intoleransi ini jika tidak dikelola dengan baik akan sangat berbahaya bagi keberlangsungan kehidupan damai di Karanganyar maupun Boyolali (Data PSAP Januari-Juli 2017).

Data kedua, Kasus Bedah buku di IAIN Surakarta

"Rektor IAIN tidak patuh pada ulama"

"Bebaskan IAIN dari faham syiah"

Tindak tutur pada data di atas termasuk dalam tuturan perlokusi yang memberikan efek pengaruh bagi yang menerimanya. Situasi yang terjadi ketika ujaran tersebut diujarkan adalah sebagai berikut:

Kronologi kejadian pelanggaran kebebasan akademik ini berawal dari agenda bedah buku yang dilakukan oleh Dewan Mahasiswa (DEMA) IAIN Surakarta pada 9 Mei 2017. Buku yang akan dibedah berjudul 
Islam Tuhan, Islam Manusia karya Dr. Haidar Bagir, diterbitkan oleh penebit Mizan, Bandung. Buku ini sebelumnya sudah pernah dibedah beberapa tempat lainnya. Agenda bedah buku ini kemudian diikuti oleh sosialisi melalui pamflet, spanduk, banner dan media sosial di lingkungan IAIN Surakarta dan sekitarnya. Rencana bedah buku tersebut direspon oleh kelompok yang menamakan dirinya Aliansi Nasional Anti Syiah (ANNAS). Mereka mengklaim sebagai kelompok yang membela paham ahlusunnah wal jamaah. ANNAS selama ini memang dikenal sebagai kelompok yang sering melakukan tekanan, intimidasi, publikasipublikasi yang masif dalam melawan paham Syiah. Di samping ANNAS ada kelompok lain yang juga melakukan tekanan pada kegiatan bedah buku di IAIN Surakarta, yaitu Laskar Umat Islam Surakarta (LUIS). Melalui pernyataannya, LUIS mengecam kegiatan bedah buku tersebut, dan mengatakan bahwa diberlangsungkannya bedah buku di IAIN Surakarta merupakan sarana penyebaran Syiah di IAIN Surakarta. LUIS merupakan kelompok yang sempat berurusan dengan pihak keamanan karena terlibat dalam kasus perusakan dan tindak penganiayaan di Cafe Sosial Kichen Solo. Baik LUIS Maupun ANNAS sama-sama menyebarkan selebaran kepada civitas akademika kampus IAIN Surakarta dan masyarakat Surakarta yang berisi seruan pembatalan kegiatan tersebut (Data PSAP Januari-Juli 2017).

Data ketiga, Perpu No. 2 tahun 2017

"Anda memasuki kawasan bebas HTI"

Situasi yang terjadi ketika tindak tutur perlokusi dimunculkan adalah sebagai berikut.

Pada bulan Mei sampai dengan Juli dukungan pada pemerintah untuk melakukan tindakan tegas pembubaran ormas yang tidak menerima Pancasila dan ingin merubah ideologi negara Pancasila dengan khilafah semakin menguat. Hal ini terlihat dari berbagai reaksi masyarakat yang menolak keberadaan ormas tersebut. Salah satu yang dengan tegas menolak keberadaan ormas yang anti Pancasila adalah Nahdhatul Ulama (NU). Dalam beberapa bulan terakhir Banser NU secara sistematis begerak melakukan penghentian pada kegiatan ormas anti Pancasila dan memasang berbagai spanduk dukungan pada NKRI. Selain NU ada juga berbagai aliansi Masyarakat, seperti Aliansi Masyarakat Karanganyar Cinta NKRI, yang juga mendorong pemerintah melakukan penertiban pada organisasi yang menolak Pancasila, salah satu yang disasar ada Hizbut Tahrir Indonesia (HTI) Situasi ini terus memanas, selama bulan Mei 2017, terjadi hampir disetiap kabupaten kota di Solo Raya. Bahkan di kabupaten Sragen dan Sukoharjo dengan tegas Gerakan Pemuda Ansor menolak acara apapun yang berbau HTI. Salah satunya adalah penolakan pada tabligh akbar yang diselenggarakan masjid raya Sragen dengan menghadirkan Felix Siaw (anggota HTI) sebagai pembicaranya (Data PSAP Januari-Juli 2017).

Data keempat, Kasus Ujaran Kebencian di Klaten: "Penistaan Agama"

Kasus yang dinilai sebagai bentuk penistaan atau penodaan agama ini bermula dari media sosial Facebook dengan nama pemilik akun Rozaq. Dalam akun $F b$-nya, Rozaq menyatakan: "satu-satunya agama yang suka mencaci adalah agama Islamnya Indonesia." Tuturan Rozaq melalui akun $F b$ merupakan tindak tutur perlokusi yang memiliki pengaruh pola pikir pada para pembaca, misalnya menumbuhkan stereotip untuk membenci Islam. Dapat disimpulkan ujaran kebencian tersebut bisa menimbulkan rasa kebencian dan permusuhan bahkan konflik horizontal di tengah masyarakat.

Data (5) Kasus Siar Kebencian "Menghina Ketua Umutr5m PBNU"

Sofyan Wahyudi (Abu Sofyan) mengunggah tulisan, "Kelakuan orang jahill Kurofat... Bertopengkan Agama Islam..." Di bawah tulisan tersebut juga diunggah foto Ketua PBNU KH Prof. Said Aqil Siroj dengan tambahan tulisan Ulamanya, ketua PP GP Ansor Yaqut Qoulil Qomas, ketua ormasnya dan foto Ansor Banser pengikutnya.

Tuturan "Kelakuan orang jahill Kurofat... Bertopengkan Agama Islam..." merupakan bentuk tindak tutur perlokusi yang menimbulkan adanya stereotip untuk membenci seseorang. Hal ini tergolong dalam sikap pembunuhan karakter seseorang melalui ujaran kebencian. 
Data (6) KONNAS: "Penodaan Agama" oleh Victor Laeskodat

Pada hari Jumat, 4 November 2017, ratusan umat Islam Solo raya memgatasnamakan KONNAS (Komunitas Nahi Munkar Surakarta) mendatangi Mapolresta Solo, jalan Adi Sucipto 2, Manahan, Banjarsari, Solo meminta Viktor Laeskodat, politisi partai Nasdem yang dinilai telah malakukan penistaan agama dan melakukan ujaran kebencian untuk terus diproses hukumnya sebagaimana Ahok. Dalam pernyataannya orator dari KONNAS mengatakan: "telah nyata umat Islam hari ini sedang dipermainkan, maka tidak boleh berdiam diri." (Data PSAP Juli-Desember 2017).

\section{Data (7) Puisi Sukmawati}

Puisi Sukmawati Soekarnoputri yang berjudul "Ibu Indonesia" mendapat sorotan publik. Syair pada puisi tersebut dinilai melecehkan dan menistakan agama, khususnya agama Islam. Puisi tersebut dinilai oleh sebagian kalangan telah menghina umat Islam. Maka Sukmawati diminta segera mengklarifikasi maksud dari puisi tersebut, karena menyinggung soal azan dan cadar. Imbasnya pemberitaan ini di daerah adalah pada 13 April 018 massa aksi FPI dan FUIS Sragen berkumpul di Masjid Al Falah Sragen. Mereka lalu melakukan long march ke Mapolres Sragen yang berjarak kurang lebih 1 $\mathrm{km}$. Mereka mendesak kepada aparat kepolisian segera menangkap Sukmawati yang dianggap menghina umat Islam lewat puisi berjudul Ibu Indonesia (Data PSAP Januari-Juli 2018).

Data (8) Kasus Pilgub Jateng

Akun twitter @ganjar2periode memposting sebuah foto bertuliskan"Jangan pilih Sudirman Said. Dia ternyata merupakan keturunan Kristen yang berkedok Islam." Kicauan itu disertai dua foto Sudirman Said, salah satunya, foto wajah Sudirman dengan background bendera Israel. Kicauan itu pun 39 kali dibagikan dengan 112 komentar dan 40 'like'. Rupanya postingan tersebut disebarkan juga lewat sejumlah grup WhatsApp (WA). Ganjar Pranowo sendiri sudah mengomentari akun palsu tersebut melalui twitter-nya pada akun @ganjarpranowo pada 14 Februari pukul
17.54. Ia menyayangkan penggunaan namanya sebagai akun memfitnah lawan politik.

"Kenapa kalian tega menggunakan nama saya untuk memfitnah orang?", tulis Ganjar (Data PSAP Januari-Juli 2018).

\section{Data (9) Cornelis -ISAC}

Pidato Cornelis ini bisa tergolong memecah-belah bangsa Indonesia dan termasuk ujaran kebencian, selain akan mengganggu hubungan antarumat beragama, pidato Cornelis ini dapat memicu kemarahan dan gejolak di antara pimpinan Ormas Islam. Endro menambahkan bahwa hal ini juga menyangkut nama baik keturunan dan pewaris kerajaan Melayu dan Islam. Dalam video berdurasi 2 menit 39 detik itu, tampak Cornelis sedang menyampaikan pidato terkait persoalan mental bangsa Indonesia, berikut kutipan pidato tersebut.

“...terlalu lama dijajah oleh kerajaankerajaan, kerajaan Majapahit, Sriwijaya yang paling parah Kerajaan Melayu dan Islam. Bersama dengan Belanda menjajah kita berabad-abad, sehingga mental kita, mental hamba, bukan mental kuli."

Tak hanya Melayu dan Islam, Kerajaan Majapahit, Sriwijaya dan kerajaan lain di Nusantara ini juga disebut sebagai "penjajah" oleh Cornelis, ujar Endro. Sekjen ISAC ini pun berharap semua pimpinan di negeri ini agar arif dan bijaksana serta menjaga keyakinan dan menghormati agama orang lain (Data PSAP Januari-Juli 2018).

Berdasarkan kelas bentuk-bentuk ujaran kebencian di atas, maka data yang dipaparkan tergolong ke dalam beberapa jenis ujaran kebencian yakni, (1) penghinaan; (2) provokasi; (3) penindasan; (4) ujaran kejahatan. Jenis-jenis ujaran kebencian tersebut merupakan bentuk perlokusi karena menimbulkan daya pengaruh seseorang atau menimbulkan stereotip buruk. Tindak tutur perlokusi merupakan sebuah tuturan yang mengacu pada efek yang ditimbulkan oleh ujaran. Tindak perlokusi menghasilkan efek atau hasil, yaitu hasil atau efek yang ditimbulkan oleh ungkapan itu pada pendengar, sesuai dengan situasi dan kondisi pengucapan kalimat itu. Tanggapan tersebut tidak hanya berbentuk kata-kata, tetapi juga berbentuk tindakan atau perbuatan (16). 
Misalnya pada data (1), bentuk ujaran pada data tersebut dapat digolongkan kelas provokasi yang berimbas pada penindasan kelompok tertentu. Konteks pragmatik pada data (1) adalah penolakan pembangunan gedung MTA, dari konteks tersebut mucul ujaran perlokusi "anti MTA" "bantai MTA" yang memberi daya pengaruh kepada pendengar/pembaca berupa tindakan atau perbuatan. Sama halnya dengan data lain yang memiliki konteks dalam hal ujaran dan pemaknaan secara pragmatik. Seperti data (8) yang berupa bentuk ujaran kejahatan yang berimbas pada provokasi. Konteks ujaran pada data (8) hanya muncul ketika musim pilihan gubernur. Maka muncullah bentuk ujaran perlokusi "Jangan pilih Sudirman Said. Dia ternyata merupakan keturunan Kristen yang berkedok Islam." Ujaran tersebut tergolong ujaran yang mampu membuat orang yang mengetahuinya terpengaruh untuk tidak memilih Sudirman Said, atau dapat pula terpengaruh dalam hal tindakkan, misalnya meminta klarifikasi perihal tersebut, karena tergolong ujaran kebencian yang membunuh karakter seseorang.

Menurut Surat Edaran (SE) Kapolri No. 6/X/2015 tentang Ujaran Kebencian, menyangkut pokok-pokok di antaranya: (1) berdampak merendahkan harkat dan martabat manusia dan kemanusiaan; (2) dapat merongrong prinsip berbangsa dan bernegara yang ber-Bhinneka Tunggal Ika serta melindungi keragaman kelompok; (3) dapat berbentuk, antara lain: penghinaan, pencemaran nama baik, penistaan, perbuatan tidak menyenangkan, provokasi, hasutan, dan penyebaran berita bohong atau fitnah; (4) dapat bertujuan untuk menghasut dan menyulut kebencian terhadap individu dan/atau kelompok dalam masyarakat yang dibedakan dari aspek suku, etnis, ras, agama, keyakinan, kepercayaan, antargolongan, warna kulit, gender, kaum difabel, dan orientasi seksual; (5) dapat dilakukan melalui berbagai media, seperti orasi publik, spanduk, banner, jejaring media sosial, demonstrasi, ceramah keagamaan, media massa, dan pamflet.

\section{b. Pusat Studi Agama Perdamaian (PSAP) sebagai Usaha Meminimalisasi Ujaran Kebencian}

Indonesia dengan keanekaragaman budaya, agama, suku, bahasa yang dimilikinya mentasbihkan dirinya sebagai salah satu bangsa yang memiliki masyarakat multikultural. Keanekaragaman tersebut menjadi sebuah rahmat tersendiri baginya jika dapat dikelolah dengan baik, bahkan menjadi keunikan dan kekuatan tersendiri (3). Namun, realitas pluralitas demikian juga dapat menjadi tantangan besar jika tidak disikapi dengan bijak dan arif, bahkan juga dapat menjadi ancaman perpecahan dan perseteruan yang dapat mengoyak keamanan sosial (9). Misalnya paham-paham ekstrimis dan radikalis yang dianggap dapat menjadi pemicu adanya perpecahan. Dapatkah dari yang berbeda tersebut dapat saling menghormati, tidak saling menyalahkan, tidak menyatakan paling benar sendiri, dan bersedia berdialog, sehingga tercermin bahwa perbedaan itu benar-benar rahmat. Jika ini yang dijadikan pijakan dalam beramal dan beragama, maka inilah sebenarnya makna konsep "Islam moderat". Artinya, siapa pun orangnya yang dalam beragama dapat bersikap sebagaimana kriteria tersebut, maka dapat disebut berpaham Islam yang moderat.(1) Islam merupakan agama rahmat seluruh alam semesta. Agama rahmat tidak berada pada titik ekstrim dan berlebihan (tatharruf). Islam selalu hadir dengan solusi representatif yang dapat diterima oleh akal sehat dan fitrah manusia, karena Islam adalah agama fitrah.

Moderasi Islam di tengah-tengah kemelut dan kegaduhan berkehidupan beragama perlu diterapkan. Tidak sekadar teori yang menyatakan Islam adalah agama damai, agama yang santun dan mampu menghargai perbedaan. Teori dan pemahaman saja tidak cukup, sebab perpecahan tidak dapat diselesaikan hanya dengan teori. Namun, perlu adanya bukti aktualisasi diri, misalnya dengan membentuk wadah sebagai sarana komunikasi dan diskusi untuk menangkal ujararan kebencian yang semakin merajalela di ruang publik. Misalnya, bentuk aktualisasi yang ada di wilayah Solo Raya dengan membentuk suatu lembaga yang membawahi beberapa maksud salah satunya adalah untuk menciptakan suasana nyaman, tenteram, damai agar rasa kenikmatan dalam beribadah dapat dirasakan oleh setiap elemen masyarakat penganut agama. Lembaga tersebut adalah Pusat Studi Agama dan 
Perdamaian (PSAP) yang didirikan pada tahun 2014 di wilayah Solo.

Lembaga PSAP bertujuan mewujudkan persaudaraan kemanusiaan melalui pemberdayaan masyarakat agar bisa berpartisipasi secara aktif dalam proses pembangunan perdamaian, kesejahteraan, keadilan, demokrasi dan kelestarian lingkungan hidup di kota Surakarta dan sekitarnya. Untuk mewujudkan tujuan tersebut PSAP difungsikan sebagai; (1) menjadi tempat kajian agama-agama dan filsafat, (2) menjadi tempat pergulatan intelektual dan pengembangan wacana dalam bidang perdamaian, keadilan, demokrasi, gender, kearifan lokal dan kelestarian lingkungan hidup; (3) menjadi fasilitator pemberdayaan masyarakat lintas agama, suku, dan golongan. (4) Menjadi pendamping bagi masyarakat korban konflik sosial dan agama, pelanggaran Hak Asasi Manusia (HAM), dan kerusakan lingkungan hidup.

Sejak tahun 2016 PSAP memiliki program yang spesifik tentang menangkal ujaran kebencian. Program ini berkaitan dengan; (1) melakukan riset tentang ujaran kebencian, (2) melakukan pemantauan uajaran kebencian, (3) penguatan tokoh agama dalam menangkal ujaran kebencian, (4) membangun net working upaya menangkal ujaran kebancian, (5) melakukan Talkshow dalam upaya menangkal ujaran kebencian. Selain itu PSAP juga memiliki program untuk dialog antaragama di lokal Solo.

\section{Kesimpulan}

Dari pemaparan data di atas, semua bentuk ujaran jika dikaitkan dengan keilmuan pragmatik, maka semuanya termasuk dalam kategori tindak tutur perlokusi, sebab semuanya mengarah pada daya pengaruh seseorang atau menimbulkan stereotip buruk. Berdasarkan kelas bentuk-bentuk ujaran kebencian, maka data yang dipaparkan tergolong ke dalam beberapa jenis ujaran kebencian yakni, (1) penghinaan; (2) provokasi; (3) penindasan; (4) ujaran kejahatan. Bentuk-bentuk ujaran kebencian dapat memberikan pemahaman tentang kata atau kalimat yang pada dasarnya mengandung ujaran kebencian. Terlebih ujaran-ujaran yang tersebar di ruang publik dan bersifat perlokusi atau dapat menimbulkan pengaruh bagi pembaca.
Moderasi Islam sebagai salah satu konsep menangkal ujaran kebencian tidak hanya terfokus pada teori akan tetapi bentuk aktualisasi diri. Diperlukan wadah sebagai sarana komunikasi dan diskusi untuk mengikis ujaran-ujaran kebencian. Misalnya terbentuknya lembaga PSAP Solo Raya sebagai salah satu wujud usaha meminimalisasi ujaran kebencian. Dengan pengenalan lembaga, komunitas, atau organisasi seperti PSAP diharapkan dari penelitian ini akan menimbulkan keinginan bagi pembaca untuk membentuk komunitas sosial kemanusiaan yang memiliki kontribusi dalam meminimalisasi ujaran kebencian. Dengan demikian, akan terbentuk lapisan kemanusiaan yang damai tanpa ada syiar kebencian, sebab pada dasarnya kebencian akan memecah belah sedang kedamaian akan mempersatukan perbedaan.

\section{References}

1. Abdurrohman A. Eksistensi Islam Moderat Dalam Perspektif Islam [Online]. Rausyan Fikr 14, 2018. http://jurnal.umt.ac.id/index.php/rf/artic le/view/671 [23 May 2019].

2. Dalimunthe I. TGB: Ujaran Kebencian Berbasis Agama Pasti Menghancurkan [Online]. CNN Indonesia: 2018. https://www.cnnindonesia.com/nasiona 1/20180727152701-32-317494/tgbujaran-kebencian-berbasis-agama-pastimenghancurkan [23 Nov. 2018].

3. Darlis. Mengusung Moderasi Islam di Tengah Masyarakat Multikulturral. Rausyan Fikr 13, 2017.

4. Fitriani F, Fitriani SS. Analisis Tindak Tutur dalam Novel Marwah di Ujung Bara Karya R.H Fitriadi. Master Bahasa 5: 51-62, 2017.

5. Harefa NR, Syahrin A, Mulyadi M. Implikasi Perubahan Undang-Undang Informasi dan Transaksi Elektronik terhadap Tindak Pidana Ujaran Kebencian (Hate Speech). Jurnal Hukum. .

6. Hermaji B. Tindak Tutur Penerimaan dan Penolakan dalam Bahasa Indonesia. Jurnal Cakrawala 7: 1-10, 2013. 
7. Komisi Nasional HAM. Buku Saku Penanganan Ujaran Kebencian (Hate Speech). Jakarta: Komisi Nasional Hak Asasi Manusia Republik Indonesia, 2015.

8. Kountur R. Metode Penelitian untuk Penulisan Skripsi dan Tesis. Jakarta: Percetakan Buana Printing, 2009.

9. Kusuma S, Lubis DP. Media Sosial dan Kebijakan KAPOLRI Mengenai "Hate Speech" (Ujaran Kebencian). Jurnal Komunikasi Pembangunan 14, 2016.

10. Leech G. Pragmatics. New York: Cambridge University Press, 1983.

11. Leech G. Prinsip-Prinsip Pragmatik. Jakarta: UI-Press, 1993.

12. Maimunah SA. Kajian Pragmatik Penggunaan Bentuk Pertanyaan Dalam Alquran Terjemahan. Departemen Agama, 1993.

13. Mawarti S. Fenomena Hate Speech Dampak Ujaran Kebencian. TOLERANSI: Media Komunikasi Umat Beragama 10, 2018.

14. Pamungkas JA, Helmi MI. Tindak Pidana Ujaran Kebencian Di Media Sosial. Jurnal Sosial Budaya Syar-i 4, 2017.
15. Rofiq FA. Analisa Redaksi Tindak Tutur Imperatif dalam Surat AlBaqarah. Kodifikasia 9, 2015.

16. Umaroh L, Kurniawati N. Dominasi Ilokusi dan Perlokusi dalam Transaksi Jual Beli. Lensa: Kajian Kebahasaan, Kesusastraan dan Budaya 7: 21-34, 2016.

17. Wijana IDP, Muhammad Rohmadi. Analisis Wacana Pragmatik. Surakarta: Yuma Pustaka, 2009.

18. Wijayanto DE. Tinjauan Yuridis Ujaran Kebencian di Media Sosial Ditinjau dari Undang Undang No 11 Tahun 2008 Tentang Informasi dan Transaksi Elektronik yang Telah Diperbarui di Dalam Undang Undang No 19 Tahun 2016 Tentang Informasi dan Transaksi Elektronik. JIFH 5: 35, 2017.

19. Yuliana ME, Nugrahaningsih W. Ujaran Kebencian dalam Komentar Akun Instagram. Surakarta: STMIK Duta Bangsa Surakarta, 2017. 